\title{
TINDAK TUTUR GURU DALAM PEMBELAJARAN BAHASA INDONESIA DI KELAS XII SMK NEGERI 1 NARMADA
}

\author{
Munawir \\ Guru SMK Negeri 1 Narmada
}

\begin{abstract}
Abstrak
Guru sebagai insan akademik memiliki peranan untuk menyampaikan materi pembelajaran kepada siswa. Dalam kegiatan penyampain materi pembelajaran, bahasa merupakan media yang digunakan dalam tindak tutur antara guru dan siswa dalam proses belajar mengajar. Dengan adanya penggunaan bahasa dalam proses pembelajaran yang dilakukan oleh guru khususnya guru mata pelajaran bahasa Indonesia hal ini sangatlah menarik untuk dilakukan penelitian. Mengingat guru bahasa Indonesia adalah pengajar yang mengajarkan tentang penggunaan bahasa dalam bahasa lisan maupun tulisan. Tujuan dari penelitian ini yaitu, 1) mendeskripsikan bentuk tindak tutur guru dalam pembelajaran bahasa Indonesia di kelas XII SMK Negeri 1 Narmada, 2) menjelaskan strategi tindak tutur guru dalam pembelajaran bahasa Indonesia di kelas XII SMK Negeri 1 Narmada. Untuk mencapai tujuan tersebut, metode yang digunakan dalam penelitian ini adalah metode penelitian deskriptif kualitatif, data penelitian ini yaitu tuturan guru dalam proses belajar mengajar di kelas. Sedangkan teknik yang digunakan untuk mengumpulkan data yaitu teknik observasi, Teknik rekam dan Teknik wawancara, sumber data dalam penelitian ini diambil dari guru bahasa Indonesia yang mengajar di kelas XII SMK Negeri 1 Narmada. Adapun hasil penelitian ini yaitu, bentuk tindak tutur guru dalam pembelajaran di kelas ada tiga yaitu, 1) tindak tutur deklaratif, 2) tindak tutur interogatif, dan 3) tindak tutur imperatif. Sedangkan strategi tindak tutur yang digunakan ada 2 yaitu, 1) strategi tindak tutur langsung, dan 2)strategi tindak tutur tidak langsung.
\end{abstract}

Kata Kunci: Tindak tutur, guru bahasa Indonesia

\section{PENDAHULUAN}

Penggunaan bahasa dalam interaksi belajar mengajar termasuk saat pembelajaran di kelas dapat dikatakan sebagai peristiwa tutur.Menurut Hymes (dalam Yule, 1988:10) disebut sebagai rangkaian ujaran peserta tutur.Rangkaian ujaran tersebut berupa percakapan yang dibangun oleh penutur $(\mathrm{Pn})$ dan mitra tutur (Mt).Sementara itu, tuturan peserta tutur dapat dikatakan sebagai tindak tutur. Richard (1995:6) menjelaskan bahwa dalam kaitannya dengan kegiatan bertutur sebagai aktivitas komunikasi, kegiatan bertutur adalah suatu tindakan.Jika kegiatan bertutur dianggap sebagai tindakan, berarti setiap kegiatan bertutur atau kegiatan menggunakan tuturan terjadi tindak tutur.Hakikat tindak tutur itu adalah maksud tuturan sebagai tindakan yang dinyatakan dengan tuturan.Tindak tutur merupakan unit terkecil aktivitas bertutur (percakapan atau wacana) yang terjadi dalam interaksi sosial.

Berdasarkan uraian yang telah di sampaikan di atas, dapat dikatakan bahwa 
dalam konteks interaksi sosial termasuk saat interaksi belajar mengajar di kelas penggunaan bentuk dan strategi tindak tutur guru dapat bervariasi. Guru dapat menggunakan bentuk tindak tutur dengan tuturan bermodus deklaratif, interogatif, dan imperatif. Tuturan bermodus deklaratif adalah tuturan yang seraca konvensional (secara umum) dapat digunakan guru untuk menyampaikan informasi, tuturan interogatif secara konvensional dapat digunakan untuk bertanya, dan tuturan imperatif secara konvensional dapat digunakan untuk memerintah. Selain penggunaan bentuk tindak tutur, guru juga dapat menggunakan strategi tindak tutur langsung dan tidak langsung dengan menggunakan tuturan yang berbeda-beda. Penggunaan strategi tindak tutur guru semestinya memperhatikan prinsip kerja sama agar jelas, mudah dipahami, padat, ringkas, dan selalu pada persoalan, sehingga mudah dipahi oleh siswa. Dengan penggunaan strategi tindak tutur yang demikian itu, dapat tercipta suasana kelas yang menarik perhatian dan dapat memotivasi belajar siswa dengan baik dan sungguh-sungguh sehingga tujuan pembelajaran tercapai.

Hal tersebut di atas, sekaligus menjelaskan bahwa penggunaan bahasa dalam interaksi belajar mengajar memberikan gambaran terhadap penggunaan tindak tutur guru yang berlangsung dalam proses belajar mengajar di kelas dan pengaruhnya terhadap suasana kelas. Apabila tindak tutur guru kurang relevan dengan konteks pembelajaran dan prinsip-prinsip penggunaan bahasa, akibatnya proses belajar mengajar bisa jadi terhambat. Informasi yang disampaikan oleh guru tidak dapat tersampaikan dan diterima dengan baik oleh siswa. Begitu pula sebaliknya, apabila guru menggunakan tindak tutur yang relevan dengan konteks pembelajaran dan prinsipprinsip penggunaan bahasa, maka dalam proses belajar mengajar akan tercipta suasana kelas yang menarik perhatian dan dapat memotivasi belajar dengan baik dan sungguh-sungguh. Informasi yang disampaikan oleh guru dapat tersampaikan dan diterima dengan baik oleh siswa, serta mendukung tercapainya tujuan pembelajaran.Oleh karena itu, fenomena tindak tutur guru dalam pembelajaran menarik untuk dikaji secara sistematis melalui penelitian. Dengan demikian penelitian ini sangat penting untuk dilakukan pada guru mata pelajaran Bahasa Indonesia dalam melakukan tindak tutur dalam proses pembelajaran di kelas.

\section{METODE PENELITIAN}

Rancangan atau desain penelitian dalam arti sempit dimaknai sebagai suatu proses pengumpulan dan analisis data penelitian. Dalam arti luas rancangan 
penelitian meliputi proses perencanaan dan pelaksanaan penelitian sampai dengan penyajian hasil penelitian. Data penelitian tindak tutur ini sesuai dengan pendekatan kualitatif yaitu menyajikan data dan menganalisisnya sesuai dengan sifat alamiah data yang didapat dari hasil penelitian.

metode kualitatif menyajikan data yang sebenarnya tanpa melalui rekayasa.

Data penelitian merupakan masalah yang dikaji dalam suatu penelitian (Arikunto, 2009:45). Metode ini digunakan mengingat data dalam penelitian berupa tuturan.Selain itu data juga diungkapkan dalam bentuk kalimat bukan melaui tanda atau lambang tertentu. Cocok untuk dipakai oleh peneliti yang memiliki objek yaitu tindak tutur guru dalam pembelajaran bahasa Indonesia. Data penelitian ini ada dua jenis, yaitu (1) data berupa tuturan guru dalam percakapan saat pembelajaran di kelas, dan (2) data catatan lapangan (data hasil wawancra dengan guru). Sedangkan teknik yang digunakan untuk mengumpulkan data yaitu teknik observasi, Teknik rekam, dan teknik wawancara. Adapun langkah-langkah dalam menganalisis data yang digunakan dalam penelitian ini yaitu menggunakan analisis data kualitatif yang dipaparkan oleh Miles dan Huberman (dalam Sugiyono, 2006:
337), yaitu reduksi data, penyajian data, dan verifikasi data atau penarikan kesimpulan.

\section{HASIL DAN PEMBAHASAN}

Hasil penelitian menunjukkan bahwa tindak tutur yang dilakukan oleh guru mata pelajaran bahasa Indonesia dalam pengajaran yang dilakukan pada kelas XII di SMK Negeri 1 Narmada, adanya tindak tutur yang dilakukan oleh guru dalam penyampaian tindak tutur guru dalam pembelajaran bahasa Indonesia di kelas XII SMK Negeri 1 Narmada diwujudkan dengan bentuk tuturan deklaratif, interogatif, dan imperatif.

1) Tindak Tutur Deklaratif

Tindak tutur deklaratif adalah tuturan yang secara konvensional (pada umumnya) digunakan untuk kalimat berita/menyampaikan informasi.

Tuturan berikut merupakan tuturan deklaratif yang digunakan guru saat proses belajar mengajar di kelas.

1) Guru : Untuk yang bersedia maju pertama ibu kasih bonus. tidak usah takut justru yang mau mencoba itu bagus dibandingkan yang tidak mau mencoba. Bukankah berani itu lebih bagus.

Siswa : Iya bu.

Siswa : (salah satu siswa mengancungkan tangan) 
Tuturan yang digunakan guru dalam percakapan di atas merupakan tuturan yang diwujudkan dengan bentuk tuturan deklaratif/menggunakan kalimat berita, yaitu terlihat dalam tuturan "untuk yang bersedia maju pertama ibu kasih bonus".

Pada tuturan tersebut guru menyampaikan informasi kepada siswa bahwa siapa yang bersedia maju pertama akan diberikan nilai bonus.

Selain merupakan kalimat berita tuturan guru pada percakapan di atas juga menunjukan adanya penggunaan fungsi direktif meminta dengan tujuan agar siswa maju ke depan dan melalukan apa yang diminta.

2) Guru : bagus sekali, tidak apaapa ya yang penting dicoba dulu sambil belajar.

Siswa : iya bu, tapi lupa-lupa ingat

Guru : itu karena kalian jarang baca buku pasti

Siswa : (senyum-senyum)

Tuturan yang digunakan guru dalam percakapan di atas juga merupakan tuturan yang diwujudkan dengan bentuk tuturan deklaratif/menggunakan kalimat berita, yaitu terlihat dalam tuturan "bagus sekali, tidak apa-apa ya yang penting dicoba dulu sambil belajar".Tuturan guru tersebut bertujuan menyampaikan informasi kepada siswa bahwa tidak perlu takut salah untuk melakukan sesuatu yang penting sudah berani mencoba.

Selain merupakan kalimat berita tuturan guru pada percakapan di atas juga menunjukan adanya penggunaan fungsi ekspresif memuji yang terlihat pada tututran "bagus sekali", dengan tujuan memberikan semangat pada siswa yang sudah berani mencoba.

2) Tindak Tutur Interogatif

Tindak tutur interogatif adalah tuturan yang secara konvensional (pada umumnya) digunakan untuk kalimat tanya.

Tuturan berikut merupakan tuturan interogatif yang digunakan guru saat proses belajar mengajar di kelas.

3) Guru : iya bagus sekali. Untuk penampilan ke dua siapa lagi?

Siswa : saya bu

Guru : kenapa yang cewek aja yang berani yang cowok kok tidak ada yang berani maju? Iya Ninin silahkan

Siswa : masih malu-malu bu (senyum-senyum).

Tuturan yang digunakan guru dalam percakapan di atas merupakan tuturan yang diwujudkan dengan tuturan interogatif/menggunakan kalimat tanya, yaitu terlihat dalam tuturan "Untuk penampilan ke dua siapa lagi?’.Kalimat tersebut disampaikan oleh guru kepada siswa dengan bertanya siapa yang akan maju untuk penampilan selanjutnya. Selain bertujuan untuk bertanya tuturan guru pada 
percakapan di atas juga menunjukan adanya penggunaan fungsi meminta kepada siswa untuk tampil.

Penggunaan kalimat tanya juga terlihat dalam tuturan "kenapa yang cewek aja yang berani yang cowok kok tidak ada yang berani maju? Iya Ninin silahkan".Pada tuturan tersebut guru menyampaikan pertanyaan kepada siswa kenapa yang cewek aja yang mengancungkan tangan untuk tampil sedangkan yang cowok tidak. Selain bertujuan untuk bertanya tuturan guru pada percakapan di atas juga menunjukan adanya penggunaan fungsi direktif meminta yang terlihat pada tuturan "iya Ninin silahkan", dengan tujuan meminta salah satu siswanya untuk tampil.

4) Guru : kemudian yang terakhir ada yang masih ingin bertanya, menyanggah atau berkomentar? Muamar?

Siswa : tidak bu.

Tuturan yang digunakan guru dalam percakapan di atas juga merupakan tuturan yang diwujudkan dengan tuturan interogatif/menggunakan kalimat tanya, yaitu terlihat dalam tuturan "kemudian yang terakhir ada yang masih ingin bertanya, menyangkah atau berkomentar? Muamar?".Tuturan guru tersebut bertujuan menanyakan kepada siswa apakah ada yang ingin bertanya atau berkomentar.
Selain bertanya tuturan guru tersebut juga menunjukan adanya penggunaan fungsi direktif meminta, yaitu guru sengaja meminta salah satu siswanya "Muamar" agar dapat memberikan komentar dimaksudkan untuk mengaktifkan siswa saat prosses pembelajaran.

3) Tindak Tutur Imperatif

Tindak tutur imperatif adalah tuturan yang secara konvensional (pada umumnya) digunakan untuk perintah/ajakan.

Tuturan berikut merupakan tuturan imperatif yang digunakan guru saat proses belajar mengajar di kelas.

5) Guru : iya kepada Rizka Permatasari silahkan untuk tampil di depan, kita berikan tepuk tangan kepa Rizka

Siswa : (tepuk tangan serentak)

Tuturan yang digunakan guru dalam percakapan di atas merupakan tuturan yang diwujudkan dengan bentuk tuturan imperatif/menggunakan kalimat perintah, yaitu terlihat dalam tuturan "iya kepada Rizka Permatasari silahkan untuk tampil di depan, kita berikan tepuk tangan kepa Rizka".Pada tuturan tersebut guru menggunakan kalimat perintah yang terkesan halus yaitu menggunakan kata silahkan yang bertujuan untuk memerintah salah satu siswanya untuk tampil di depan. 
Selain merupakan kalimat perintah tuturan guru pada percakapan di atas juga menunjukan adanya penggunaan fungsi direktif meminta kepada siswa lainya untuk memberikan tepuk tangan kepada temannya yang akan tampil.
6) Guru : Ya Ninin bisa di mulai sekarang, yang lain tolong diam.

Siswa : Baik bu.

Tuturan yang digunakan guru dalam percakapan di atas juga merupakan tuturan yang diwujudkan dengan tuturan imperatif/menggunakan kalimat perintah, yaitu terlihat dalam tuturan"ya Ninin bisa di mulai sekarang,".Pada tuturan tersebut guru menggunakan kalimat perintah untuk menyuruh siswanya segera mulai membaca. Penggunaan kalimat perintah juga terlihat dalam tuturan"yang lain tolong diam".Tuturan tersebut bertujuan untuk memerintah sekaligus meminta kepada siswanya untuk diam.

Penggunaan strategi dalam melakukan tindak tutur yang dilakukan oleh guru bahasa Indonesia pada siswa Kelas XII di SKM Negeri 1 Narmada ada dua yaitu; (1) strategi tindak tutur langsung, dan (2) strategi tindak tutur tidak langsung. Contoh dari strategi yang dimaksudkan di atas adalah sebagai berikut:

1. Strategi tindak tutur langsung
Strategi langsung yaitu strategi penyampaian tindak tutur menggunakan tuturan yang bentuknya mempunyai makna sama (atau mirip) dengan maksud pengutaraannya.

Percakapan berikut merupakan strategi tindak tutur langsung yang digunakan guru saat proses belajar mengajar di kelas.

1) Guru : Ya untuk Samsul Huda mungkin bisa di bacakan ulang apa itu teks laporan. Yang lainya tolong di simak baik-baik.

Siswa :Teks laporan adalah teks yang berisi penjabaran umum atau melaporkan sesuatu berupa hasil dari pengamatan.

Tuturan di atas disampaikan oleh guru secara langsung sesuai dengan fungsinya untuk meminta.Strategi langsung yang dinyatakan dengan fungsi direktif meminta tersebut terlihat pada tuturan "ya untuk Samsul Huda"yang dimaksudkanmeminta Samsul Huda untuk mengulang bacaaannya.

2) Guru : Ya masih bisa dimaklumi untuk hari ini, tapi untuk pertemuan berikutnya jangan sampai dilupakan lagi. Begitu juga dengan lainnya.

Siswa : Iya bu. Terima kasih.

Tuturan pada percakapan di atas menunjukkan adanya penggunaan strategi 
langsung yang ditunjukan oleh guru dengan fungsi asertif penerimaan mengenai kesalahan yang dilakukan oleh siswanya. Siswa yang merasa bersalah segera paham terhadap maksud dari tuturan guru.Hal itu dilakukan guru agar siswa dapat memperbaiki kesalahan dan tidak mengulangnya lagi.

2. Strategi tindak tutur tidak langsung Strategi tidak langsung adalah strategi penyampaian tindak tutur menggunakan tuturan yang bentuknya mempunyai makna yang tidak sama dengan maksud penuturannya.

Percakapan berikut merupakan strategi tindak tutur langsung yang digunakan guru saat proses belajar mengajar di kelas.

3) Guru :Siapa yang akan menjawab soal no.6?

Siswa : Ini $\mathrm{Bu}$, Andi mau jawab.

Tuturan pada percakapan di atas menunjukkan adanya penggunaan strategi tindak tutur tidak langsung menggunakan fungsi direktif meminta yang diwujudkan dengan kalimat tanya. Tuturan guru tersebut menunjukkan bahwa guru bertaya dengan maksud lain meminta secara tidak langsung siswa untuk memberikan jawaban ketika guru mengadakan tanya jawab terkait soal yang dibahas. Siswa segera paham maksud guru meskipun diutarakan secara tidak langsung sehingga siswa berusaha untuk menjawab dan saling menunjuk temanya untuk memberikan jawaban yang tepat. Hal itu dilakukan guru untuk mengaktifkan siswa dalam pembelajaran di kelas.

4) Guru : Ada yang bisa membantu ibu untuk membersihkan papan?

Siswa : Iya, saya bu.

Tuturan guru pada percakapan di atas menunjukkan adanya penggunaan tidak tutur tidak langsung menggunakan fungsi direktif memerintah.Tuturan guru tersebut menunjukkan bahwa guru memerintah menghapus papan. Siswa segera paham maksud guru meskipun diutarakan secara tidak langsung yaitu tanpa guru menyebutkan namanya siapa yang harus hapus papan, namun siswa cukup memahami maksud dibalik tuturan yang diutarankan guru sehingga bergegas hapus papan. Hal itu dilakukan guru untuk memusatkan perhatian agar siswa tidak ngantuk dan tetap fokus dalam mengikuti proses pembelajaran.

\section{PENUTUP}

Berdasarkan hasil analisis data yang dilakukan dalam penelitian ini dapat disimpulkan bahwa, tindak tutur yang dilakukan oleh guru mata pelajaran Bahasa Indonesia adalah sebagai berikut. 
1) Bentuk tindak tutur yang digunakan guru dalam proses pembelajaran di kelas ada tiga yaitu, tindak tutur deklaratif, tindak tutur interogatif, dan tindak tutur imperatif. 1) tindak tutur deklaratif meliputi fungsi direktif meminta, fungsi ekspresif meтuji, fungsi representatif memberikan informasi/mengemukakan pendapat. 2) tindak tutur interogatif meliputi fungsi direktif meminta, fungsi representatif menerima. 3) tindak tutur imperatif meliputi fungsi meminta.

2) Penggunaan strategi tindak tutur yang digunakan ada dua yaitu, strategi tindak tutur langsung meliputi: strategi tindak tutur langsung menggunakan fungsi direktif meminta, strategi tindak tutur langsung menggunakan fungsi representatif menerima. Strategi tindak tutur tidak langsung meliputi: strategi tindak tutur tidak langsung menggunakan fungsi direktif meminta, dan strategi tindak tutur tidak langsung menggunakan fungsi direktif memerintah.

\section{DAFTAR PUSTAKA}

Arifin, Anwar. 2012. Ilmu Komunikasi: Sebuah Pengantar Ringkas. Jakarta: PT. Raja Grafindo Persada

Abdulsyani. 1994. Sosiologi: Skematika, Teori dan Terapan. Jakarta: Bumi Aksara.
Rohmadi, Muhamad. 2011. Pragmatik Teori dan Analisi.Surakarta: YumarPustaka

Sugiono. 2010. Metode Penelitian

Pendidikan: Pendekatan

Kualitatif, Kuantitatif, dan $R \& D$. Bandung: Alfabeta

Sumarsono. 2004. Buku Ajar: Filsafat Bahasa. Jakarta: PT Gramedia Widiasarana Indonesia.

Sumarsono, dan Paina Partara. 2004.

Sosiolinguistik. Yogyakarta :

Pustaka Pelajar dan Sabda.

Sumarsono. 2010. Pragmatik. Yogyakarta : Pustaka Pelajar

Tarigan, Hendry Guntur. 2009. Pengajaran Pragmatik. Bandung: Angkasa

Wijana, I Dewa Putu. 1996. Dasar-Dasar Pragmatik. Yogyakarta: Andi 